\title{
PENINGKATAN HASIL BELAJAR PPKn MELALUI METODE DEBAT PRO DAN KONTRA PADA SISWA KELAS VIII B SMPN 3 MENGWI KABUPATEN BADUNG TAHUN PELAJARAN 2020/2021
}

\author{
I Gede Sujana \\ Universitas Dwijendra \\ dalungsujana@gmail.com
}

\begin{abstract}
ABSTRAK
Penelitian ini bertujuan untuk mengetahui peningkatan hasil belajar pada mata pelajaran PPKn melalui penerapan metode Debat pro dan kontra pada siswa kelas VIIIB SMPN 3 Mengwi Kabupaten Badung Tahun Pelajaran 2020/2021. Jenis penelitian ini menggunakan jenis penelitian tindakan kelas yang bersifat daur siklus berulang. Masing-masing siklus dilaksanakan melalui 4 tahapan yaitu perencanaan, pelaksanaan, pengamatan, dan refleksi. Pengumpulan data dilakukan melalui observasi dan tes, dengan menggunakan lembar observasi serta soalsoal tes yang dianalisis menggunakan teknik kualitatif dan kuantitatif. Subjek pada penelitian ini adalah siswa kelas VIIIB yang berjumlah 32 orang. Teknik pengumpulan data yang digunakan untuk mengukur hasil belajar siswa menggunakan data kuantitatif yaitu tes tertulis dan untuk mengukur aktivitas guru dikelas digunakan data kualitatif yaitu lembar observasi. Hasil penelitian ini menunjukkan bahwa pembelajaran metode Debat pro dan kontra memiliki dampak positif dalam meningkatkan hasil belajar siswa. Hal ini dapat dilihat dari semakin meningkatnya presentase ketuntasan belajar siswa dari siklus I dan II. Pada siklus I presentase tingkat hasil belajar mencapai $70 \%$ dan ketuntasan klasikal mencapai $90 \%$. Setelah dilaksanakan perbaikan pada tindakan siklus II presentase tingkat hasil belajar siswa mampu mencapai $85 \%$ dan ketuntasan klasikal mencapai $100 \%$. Nilai kriteria ketuntasan minimal (KKM) dari penelitian ini adalah 75.
\end{abstract}

Kata Kunci: Metode Pembelajaran Debat Pro dan Kontra, Hasil Belajar, PPKn.

\begin{abstract}
The background of this research was the low of student learning outcomes in Pancasila and Civics Education in VIIIB Grade student of SMP N 3 Mengwi Badung in academic year 2020/2021, based on the results of observations. The purpose of this research was to improve the learning outcomes of Pancasila and Civics Education through the implementation of the pro and con debate method. This research was classroom action research; a repeating cycle. Each cycle is carried out through 4 stages, namely planning, implementing, observing, and reflecting. Data were collected through observation and tests using observation sheets and test questions which were analyzed using qualitative and quantitative techniques. The subjects were 32 students of VIIIB grade. Data collection techniques used to measure student learning outcomes were using quantitative data, namely written tests and to measure teacher activity in class used qualitative data, namely observation sheets. The finding showed that the pros and cons debate learning method contributed a positive impact in improving student learning outcomes. This was reflected from the increasing percentage of student learning completeness from cycles I and II. In the cycle I, the percentage of learning outcomes reached $70 \%$ and classical completeness reached $90 \%$. After the improvement in the cycle II, the percentage of student learning outcomes reached $85 \%$ and classical completeness reached $100 \%$. The minimum completeness criteria (KKM) value of this study was 75.
\end{abstract}

Keyword: pros and cons debate learning method, Learning Achievement, PPKn.

\section{PENDAHULUAN}

Dewasa ini kerap kali ditemukan masalah Pendidikan yang menjadi topik utama. Pendidikan di Indonesia diharapkan memiliki kualitas yang mampu bersaing di kancah Internasional serta mampu menjadi warga negara yang memiliki komitmen kuat dan konsisten untuk membanggakan negara serta mempertahankan Negara Kesatuan Republik Indonesia melalui bidang Pendidikan (Santika, 2020). Bidang Pendidikan sangat berperan penting 
dalam memajukan kesejahteraan kehidupan bangsa Indonesia. Khususnya dalam proses pembelajaran ada dua pihak yang terlibat, yaitu guru dan siswa. Guru bertugas mengajar sedangkan siswa belajar. Mengajar berarti mengkomunikasikan sesuatu kepada seseorang atau sekelompok orang dengan maksud untuk mengetahui atau mengerti materi yang diajarkan. Sebaliknya, belajar dapat diartikan sebagai proses perubahan tingkah laku melalui interaksi antara individu dan lingkungan sekitarnya. Perubahan tingkah laku ini dapat berupa sikap ketrampilan dan pengetahuan. Hal ini sejalan dengan UU No 20 Tahun 2003, tentang sistem Pendidikan Nasional memberikan defenisi Pendidikan adalah "usaha sadar dan terencana untuk mewujudkan suasana belajar agar peserta didik secara aktif mengembangkan potensi dirinya untuk memiliki spiritual keagamaan, pengendalian diri, kepribadian, kecerdasan, akhlak mulia, serta ketrampilan yang diperlukan masyarakat, bangsa, dan negara Indonesia”. (Kaelan, 2004:15).

Tentang profesi guru di masa mendatang semakin berat dan semakin banyak. Oleh karena itu, seorang guru harus mampu dan berupaya meningkatkan kualitas dirinya sehingga dapat mengatasi berbagai masalah dalam menjalankan tugas serta sikap arif dan bijaksana dalam ucapan dan tindakannya. Siswa memiliki peran utama dalam proses pembelajaran karena siswa adalah subjek dan bukan objek dari pengajar. Realita proses pembelajaran yang terjadi di sekolah-sekolah selama ini sama sekali tidak memberikan peluang kepada siswa atau peserta didik untuk mengembangkan keaktivitasan dan kemampuan berpikir kritis peserta didik. Peserta didik masih saja menjadi objek. Bagi anak yang agresif proses pengembangan diri akan berjalan bila diberikan kesempatan cukup untuk beraksi. Sebaliknya bagi anak yang pasif, peran guru dan guru sebagai fasilitator sangat dibutuhkan untuk pengembangan diri siswa secara maksimal.

PPKn adalah salah satu disiplin ilmu yang banyak memberi bantuan untuk kepentingan kehidupan umat manusia di dalam menyelesaikan problem-problem kehidupan sehari-hari, akan tetapi bagi kebanyakan siswa, PPKn adalah bukan yang menyenangkan, sehingga konsekuensinya rasa tidak senang pada pelajaran PPKn belum mencapai hasil yang optimal sesuai dengan target yang diharapkan (Santika, 2021).

Tujuan seorang guru dalam menyampaikan materi pembelajaran kepada siswa tidak mudah. Guru harus mempunyai kemampuan yang sangat menunjang tugas agar tujuan Pendidikan dicapai. Salah satu kemampuan yang dimiliki oleh seorang guru dalam proses meningkatkan profesinya adalah kemampuan mengembangkan metode pembelajaran. Dalam mengembangkan metode pembelajaran, seorang guru harus dapat menyesuaikan antara model yang dipilih dengan kondisi siswa, materi pembelajaran, dan sarana yang ada. Oleh karena itu guru harus menguasai beberapa model pembelajaran agar proses belajar mengajar berjalan lancar dan tujuan yang diinginkan dapat tercapai.

Proses pembelajaran saat ini kurang memiliki daya Tarik. Kurang menariknya pembelajaran karena 2 hal. Pertama pembelajaran yang dirancang oleh guru tidak dapat memacu keingintahuan siswa untuk membedah masalah seputar lingkungan sosialnya sekaligus dapat membentuk opini pribadi terhadap masalah tersebut. Kedua, guru mempromosikan diri sebagai pribadi yang menggurui, belum memerankan diri sebagai fasilitator yang membelajarkan siswa.

Dalam kegiatan belajar mengajar yang dilaksanakan di lingkup sekolah dibutuhkan berbagai 
variasi Teknik yang harus dikuasai oleh seorang guru agar proses belajar yang tercipta di kelas menjadi lebih dinamis dan bernuansa interaktif. Selain itu, variasi Teknik yang digunakan juga harus dapat membantu siswa dalam menyelesaikan tugas-tugas perkembangannya dalam fase remaja sesuai dengan pedoman psikologi individu.

Beberapa diantara tugas perkembangan tersebut menjadi landasan terciptanya metode pembelajaran kooperatif yang mengedepankan kerja sama dari para peserta didik sehingga tercipta nuansa jelas yang dinamis, interaktif, dan dapat menjadi faktor stimulan agar peserta didik dapat mengembangkan pola pikir yang kritis.

Untuk mengatasi masalah-masalah seperti yang tertera di atas, maka penulis melakukan tindakan kelas dengan menerapkan model pembelajaran debat. Pembelajaran dengan menggunakan metode debat menurut Silberman (2009) "dapat menjadi sebuah metode berharga untuk mengembangkan pemikiran dan refleksi, khususnya jika para peserta didik diharapkan mengambil posisi yang bertentangan dengan pendapatnya." Berdasarkan pendapat tersebut maka metode debat merupakan salah satu metode yang dapat digunakan dalam pembelajaran di kelas untuk mengembangkan kemampuan berpikir siswa.

Menurut Ahmadi (1997) metode pembelajaran adalah suatu pengetahuan tentang cara-cara mengajar yang dipergunakan oleh guru atau instruktur. Pengertian lain menyatakan bahwa metode pembelajaran merupakan Teknik penyajian yang dikuasai oleh guru untuk mengajar atau menyajikan bahan pelajaran kepada siswa di dalam kelas baik secara individu maupun kelompok agar pelajaran itu dapat di serap, dipahami dan dimanfaatkan oleh siswa dengan baik.
Metode debat merupakan suatu metode pembelajaran dengan memberikan sebuah isu kontroversial atau materi yang dapat diperdebatkan. Isu kontroversial yang diberikan akan membentuk dua kelompok, yaitu kelompok pro dan kontra terhadap pandangan isu kontroversial tersebut. Peserta didik menentukan pendiriannya yang bergabung dalam kelompok-kelompok sesuai dengan pendiriannya. Hal tersebut di tujukan kepada siswa untuk beradu argument dengan kelompok yang memiliki pendirian yang berbeda. Adanya perbedaan pendapat tersebut akan membuat siswa mengemukakan pendapat yang menguatkan pendirian yang telah ditentukannya. Oleh karena itu, siswa tidak akan sembarangan dalam mengemukan pendapat, tetapi mengalami proses berpikir sebelum mengemukakan pendapat. Dengan demikian, metode debat mampu membuat siswa berpikir untuk mengemukakan pendapat yang mampu mempertahankan pendapatnya.

Hingga saat ini, terdapat berbagai macam model yang digunakan dari turunan metode pembelajaran kooperatif. Salah satu dari model yang berkembang dan sering digunakan pada kegiatan belajar mengajar adalah debat. Debat digunakan pendidik dalam upaya menumbuh kembangkan pola pikir kritis dan kemampuan kerja sama antar peserta didik dalam bentuk kelompok.

\section{Tinjauan Tentang Debat}

Debat merupakan sebuah sarana yang dapat menyampaikan pendapat atau argumen seseorang. Debat yang baik merupakan cara untuk memahami orang lain, berbagi ide, dan menyepakati hal-hal yang saling menguntungkan satu dengan yang lainnya dari kedua bela pihak. Debat juga bisa melatih kebranian beragumentasi. 
Menurut Herring (2017) "setiap perdebatan menuntut seseorang pada pemahaman yang lebih baik mengenai sudut pandang lawan bicaranya dan sudut pandangnya sendiri.

Sesuai dengan pemaparan di atas, debat bukan hanya tentang pertengkaran atau adu pendapat yang tidak memiliki hasil. Debat juga dapat memberi ilmu baru bagi setiap pihak, baik pihak pro maupun kontra (Santika, 2020).

Menurut KBBI mengatakan bahwa teks ialah naskah yang berupa kata-kata asli dari pengarang atau bahan tertulis untuk dasar memberikan pelajaran, berpidato dan sebagainya. Berdasarkan pemaparan diatas penulis menyimpulkan bahwa, teks merupakan naskah atau serangkaian kata-kata yang ditulis oleh pengarang dan memiliki tujuan tertentu untuk menyampaikan maksudnya.

Menurut Tarigan (2013, hlm 92) “debat merupakan suatu argument untuk menentukan baik tidaknya suatu usul tertentu yang didukung oleh satu pihak yang disebut pendukung atau afirmatif, dan ditolak atau disangkal oleh pihak lain yang disebut penyangkal atau negative”. Ketika kita berbicara tentang bentuk bahasa, yang kita maksud adalah kata, frasa, klausa, kalimat, paragraf, dll, yang diucapkan dan ditulis (Swarniti, 2019).

Debat adalah kegiatan adu argumentasi antara dua pihak atau lebih, baik secara perorangan maupun kelompok, dalam mendiskusikan dan memutuskan masalah dan perbedaan. Selain itu debat juga sering disebut sebagai suatu pertukaran pikiran yang dilakukan oleh orang-orang yang mempunyai pandangan yang berlawanan (Santika, 2019). Pembelajaran dan model debate diawali dengan pembentukan dua kelompok, satu kelompok yang pro (setuju) dan satu kelompok lagi kontra (tidak setuju). Kedua kelompok ini duduk berhadapan dan saling beradu argumentasi dalam rangka mengemukakan pendapatnya untuk meyakinkan siswa lawan bicaranya atau kelompok lain bahwa yang dikemukakannya adalah benar. Maka adu argumentasi dalam model pembelajaran debate merupakan keharusan yang harus dilakukan setiap siswa dari masing-masing kelompok. Jadi kemampuan untuk menyampaikan pendapat sangat diperlukan dalam model pembelajaran debat ini. Dalam model pembelajaran debate ini ada suatu peraturan atau suatu keharusan bagi masing-masing kelompok untuk menyampaikan alasannya mengapa kelompoknya setuju atau tidak.

Menurut Silberman (1996), Sebuah debat bisa menjadi metoda berharga untuk meningkatkan pemikiran dan perenungan, terutama jika siswa diharapkan mengemukakan pendapat yang bertentangan dengan diri mereka sendiri. Ini merupakan strategi debat yang secara aktif melibatkan setiap siswa di dalam kelas, tidak hanya mereka yang di dalam kelas.

\section{Kekurangan dan kelebihan dari Model Pembelajaran Debat}

Kelebihan dari model pembelajaran debat yaitu:

a. Siswa akan terlatih dan terbisa mengutarakan pendapat/ pemikirannya dan mempertahankan pendapatnya dengan alasan-alasan yang logis dan dapat dipertanggungjawabkan.

b. Dapat meningkatkan daya kritis siswa dalam berpikir.

c. Dapat meningkatkan kemampuan siswa untuk menyampaikan pendapat di depan orang banyak.

d. Dapat meningkatkan kemampuan siswa untuk mengetahui pola pikir orang lain yang tidak sesuai dengannya. 
e. Dapat menggali ide-ide atau gagasangagasan cemerlang dari siswa.

f. Dapat melatih siswa untuk hidup harmonis dengan orang yang bersebrangan dengannya.

g. Memantapkan pemahaman konsep siswa terhadap materi pelajaran yang telah diberikan.

h. Melatih siswa untuk berani mengemukakan pendapat.

Kebaikan Pembelajaran Model Debat. Pembelajaran model debat baik digunakan apabila bertujuan untuk:

a. Melatih siswa untuk berpikir kritis.

b. Melatih siswa untuk menyampaikan pendapat secara baik dan benar.

c. Mencari kebenaran tentang topik yang sedang hangat atau sedang heboh-hebohnya dibicarakan di masyarakat.

d. Melatih siswa untuk memahasmi alur pikir orang lain yanga berseberangan dengannya.

e. Melatih untuk menumbuhkan ide atau gagasan baru dari hasil kajian siswa.

Kekurangan dari model pembelajaran debat yaitu: Pada satu sisi berdebat ada manfaatnya dalam rangka menambah wawasan atau menguji ketajaman berpikir dari siswa. Akan tetapi, ada juga kekurangannya, dimana kekurangannya itu meliputi:

a. Bahan dari topik yang dibicarakan kurang lengkap.

b. Masalah yang diperdebatkan kurang esensial atau bisa lari dari topik yang dibahas.

c. Perselisihan pendapat sering tidak berkesudahan.

d. Dalam berbicara didominasi oleh beberapa orang saja.

e. Tumbuhnya sikap egoisme dari siswa. f. Sulit untuk mengambil kesimpulan dari hasil pembelajaran

\section{Hasil Belajar}

Hasil belajar merupakan perubahan perilaku atau kompetensi (sikap, pengetahuan dan ketrampilan) yang diperoleh setelah melalui aktivitas belajar (Sardiman, 2010). Hasil belajar merupakan perolehan nilai yang dicapai siswa atas penguasaan/kecakapan yang diperoleh melalui proses pembelajaran yang ditunjukkan denag hasil tes ranah aektif, kognitif dan psikomotor (Santika, 2017). Keberhasilan siswa dalam proses pembelajaran dipengaruhi oleh factor internal dan factor eksternal. Termasuk dalam factor internal meliputi : intelegensi/kecerdasan, kemauan, bakat, kematangan/pertumbuhan, daya ingat. Sedangkan factor eksternal yakni factor lingkungan yang meliputi : guru (cara mengajarnya), sarana/prasarana dan motivasi social.

Perkembangan model pembelajaran debat saat ini masi berlangsung bahkan model ini diterapkan hingga menjadi jenis kompetisi antar pelajar hingga tingkat dunia. Maka dari itu penulis ingin meneliti tentang penerapan metode debat pro dan kontra dalam meningkatkan hasil belajar siswa kelas VIIIB di SMPN 3 Mengwi Badung tahun pelajaran 2020/2021. Dalam penelitian ini, penulis mengadakan kolaborasi dengan guru PPKn (Ni Gst. Ayu Rai Suartini, S.Pd.)

Berdasarkan latar belakang di atas, maka rumusan masalah dari penelitian ini adalah: Apakah dengan penerapan metode debat pro dan kontra dapat meningkatkan hasil belajar siswa kelas VIIIB SMPN 3 Mengwi Badung tahun pelajaran 2020/2021?

Sehingga tujuan yang ingin dicapai dari penelitian ini adalah untuk mengetahui peningkatan 
hasil belajar PPKn melalui penerapan metode debat pro dan kontra siswa kelas VIIIB SMPN 3 Mengwi Badung tahun pelajaran 2020/2021.

\section{METODE PENELITIAN}

Metode berarti Cara kerja yang bersistem untuk memudahkan pelaksanaan sesuatu kegiatan guna mencapai suatu tujuan yang ditentukan. Menurut WJS. Poerwadarminta dalam kamus Bahasa Indonesia, (1999) metode adalah cara yang telah teratur dan terpikir baik-baik untuk mencapai suatu maksud. Berdasarkan defenisi di atas metode merupakan jalan atau cara yang ditempuh seseorang untuk mencapai tujuan yang di harapkan.

\subsection{Jenis Penelitian}

Jenis penelitian ini penelitian tindakan kelas (PTK) yang secara umum mempunyai tujuan untuk meningkatkan hasil belajar siswa. Penelitian ini dilakukan di SMPN 3 Mengwi Kabupaten Badung.

Dalam penelitian ini terdapat 2 variabel yaitu variable bebas dan variable terikat. Variable bebas adalah suatu variable yang nantinya akan memberikan pengaruh terhadap variable terikat. Variable bebas dalam penelitian ini adalah penerapan metode debat pro dan kontra. Sedangkan variable terikat adalah variable yang menerima berbagai akibat yang disebabkan oleh variable bebas. Yang menjadi variable terikat dari penelitian ini adalah meningkatkan hasil belajar siswa kelas VIIIB SMPN 3 Mengwi Badung.

Objek dalam penelitian ini adalah terbatas pada penerapan metode debat pro dan kontra. Subjek dalam penelitian ini adalah siswa kelas VIIIB SMPN 3 Mengwi Badung.

Penelitian ini dirancang dengan penelitian tindakan kelas yang terdiri dari 2 siklus yaitu siklus I dan siklus II yang mempunyai beberapa tahap yaitu:.

\section{a.Tahap perencanaan}

Perencanaan menyusun jadwal pembelajaran, membuat program pengajaran menyusun rencana pelaksanaan pembelajaran (RPP), menyiapkan buku PPKn dan media pembelajaran.

\section{b.Tahap pelaksanaan}

Pada tahap ini merupakan implementasi dari perencanaan yang telah disusun sebelumnya sesuai dengan skenario dan perencanaan pembelajaran yang telah peneliti susun pada tahap perencanaan.

c.Tahap observasi

Mempersiapkan lembar pengamatan untuk mengamati situasi dan kondisi kegiatan pembelajaran, yaitu lembar untuk aktivitas pengajar. d.Tahap refleksi

Kegiatan evaluasi, analisis, penyimpulan dan identifikasi tindak lanjut dalam pelaksanaan siklus berikutnya.

\subsection{Lokasi Penelitian}

Lokasi penelitian merupakan tempat yang dijadikan pusat untuk melaksanakan penelitian. Adapun lokasi penelitian yang dipilih adalah SMP Negeri 3 Mengwi Kabupaten Badung dengan alamat Jalan Raya Buduk, Mengwi Kabupaten Badung. Karena penulis menemukan permasalahan terkait dengan hasil pembelajaran PPKn dengan penerapan metode debat.

\subsection{Subyek Penelitian}

Penentuan subyek dalam penelitian ini adalah dengan menggunakan Teknik Purposive (Purposive Sampling) karena berdasarkan atas pertimbangan tujuan penelitian bahwa informan/responden yang dibutuhkan untuk memberikan informasi yang dibutuhkan sudah jelas. Dalam hal ini yang menjadi subyek penelitian adalah para siswa Kelas VIIIB SMPN 3 Mengwi Badung yang berjumlah 32 orang. 


\subsection{Teknik Pengumpulan Data}

\subsubsection{Observasi}

Teknik observasi biasa diartikan sebagai pengamatan dan pencatatan dengan sistematik fenomena-fenomena yang diselidiki dengan melihat langsung ke lapangan, terhadap obyek yang diteliti. Melalui metode observasi ini, penulis akan mengamati terkait masalah yang diteliti dalam jangka waktu tertentu terkait dengan peningkatan hasil belajar dengan metode debat.

\subsubsection{Wawancara}

Wawancara atau interview adalah sebuah dialog yang dilakukan oleh pewawancara (interviewer) untuk memperoleh informasi dari terwawancara (Suharsimi, 2009). Wawancara dilakukan dengan Kepala Sekolah dan Guru PPKn kelas VIIIB dengan menggunakan pedoman wawancara yang telah disiapkan yang selanjutnya informasi tersebut dicatat secara sistematis.

\subsubsection{Dokumentasi}

Teknik dokumentasi adalah Teknik mencari data mengenai hal-hal atau variable yang berupa catatan, transkrip, buku, surat kabar, majalah, agenda dan sebagainya (Suharsimi, 2009). Dengan Teknik dokumentasi, penulis mengambil data seperti : profil sekolah, biografi, gambar-gambar pelaksanaan pembelajaran dan lain-lain.

\subsubsection{Test}

Metode tes merupakan salah satu metode yang digunakan untuk mengumpulkan data dengan memberikan tes pada siswa (Sugiyono, 2013: 235). Tes diberikan kepada siswa untuk mengetahui tingkat keberhasilan siswa dalam proses pembelajaran.

\subsection{Metode Analisis Data}

Analisis data menurut Moleong (2006) adalah "proses mengatur urut data". Adapun Teknik ang digunakan dalam penelitian ini adalah analisis dekriptif kuantitatif. Secara spesifik tahap pengumpulan data dan analisis data yang digunakan dalam penelitian ini yakni : (1) Pengumpulan data, (2) reduksi data, (3) penyajian data, (4) penarikan simpulan. (Milles dan Huberman, 2000).

\section{HASIL PENELITIAN DAN PEMBAHASAN}

\subsection{Hasil Penelitian}

\subsubsection{Gambaran Umum SMP Negeri 3 Mengwi Kabupaten Badung.}

SMP Negeri 3 Mengwi secara resmi beroperasi pada tahun 1984, dengan SK pendirian sekolah : 0176/0/1984, tanggal SK pendirian : 04-061984. Sampai saat ini jumlah guru yang dipekerjakan di SMP Negeri 3 Mengwi sebanyak 77 orang dan jumlah siswa 1101, yang terdiri dari siswa laki-laki sebanyak 563 orang dan siswa perempuan 538 orang. Tenaga Kependidikan sebanyak 27 orang.

Secara geografis SMP Negeri 3 Mengwi terletak di Jln. Raya Buduk, Br. Sengguan, Desa Buduk Kecamatan Mengwi Kabupaten Badung. Lokasi SMP Negeri 3 Mengwi merupakan wilayah yang sangat strategis, yakni berada di Kawasan perdesaan yang padat penduduk. Jaraknya kurang lebih 2,11 km dari pusat Pemerintahan Kabupaten Badung. SMP Negeri 3 Mengwi Kabupaten Badung berdiri di atas lahan seluas $7.400 \mathrm{M}^{2}$ Yang dibatasi oleh :
a. Sebelah Utara : Jalan Raya Buduk
b. Sebelah Timur : LPD Desa Adat Buduk
c. Sebelah Selatan : Perumahan
d. Sebelah Barat : Sungai.

Visi Misi SMP Negeri 3 Mengwi Kabupaten Badung.

Visi Sekolah : 
"Berprestasi, Berbudaya, dan Berwawasan Lingkungan"

\section{Indikator Visi :}

a. Unggul dalam pelaksanaan kurikulum

b. Unggul dalam pelaksanaan proses pembelajaran

c. Unggul dalam prestasi akademik

d. Unggul dalam prestasi non akademik

e. Unggul dalam segala aspek kepribadian

f. Unggul dalam penataan lingkungan

\section{Misi Sekolah.}

\section{Indicator Misi :}

a. Melaksanakan pengembangan kurikulum yang adaptif secara optimal

b. Melaksanakan proses pembelajaran yang berbasis paikem

c. Melaksanakan kegiatan keagamaan secara efektif dan optimal sesuai dengan norma agama

d. Menumbuhkan budaya gemar membaca, bekerja keras, saling menghargai, disiplin, jujur, kreatif, dan wira usaha

e. Menumbuhkembangkan penghayatan dan pengamalan terhadap ajaran agama dan kepercayaan yang dianut

f. Menciptakan suasana belajar yang demokratis, aktif, inovatif, kreatif dan menyenangkan

g. Mengembangkan budaya kompetitif dalam bidang akademik dan non akademik

h. Melaksanakan gerakan disiplin secara konsekuen bagi warga sekolah

i. Menanamkan kepedulian social dan lingkungan, berkarakter, cinta damai, cinta budaya, dan cinta tanah air, semangat kebangsaan dan hidup demokratis j. Menciptakan lingkungan sekolah yang bersih, Indah, sehat, menawan, aman dan asri (BISAMA)

\subsection{Pembahasan}

Siklus I

Seperti telah dijelaskan dalam setting penelitian, bahwa penelitian ini adalah penelitian tindakan kelas yang akan dilaksanakan dalam dua siklus yaitu siklus I dan siklus II.

Dalam siklus ini diiuraikan langkah-langkah yang ditempuh peneliti antara lain: (1) Tahap perencanaan, (2) Pelaksanaan Tindakan, (3) Tahap Observasi, (4) Tahap refleksi.

\section{Siklus II}

Pada tahap ini penulismempersiapkan pelaksaan siklus II dimana tindakan kali ini diambil dengan mempertimbangkan hasil yang diperoleh pada siklus I. penulis menyusun rencana guna mengatasi kendala-kendala yang ditemui selama pelaksanaan kegiatan siklus I. Adapun persiapan penulis antara lain:

a. Menyusun tema sesuai dengan materi bahasan

b. Mempersiapkan fasilitas atau saran yang diperluhkan selama kegiatan belajar mengajar berlansung.

c. Menetapkan kebijakan yang boleh diambil penulis apabila ada peserta yang pembicaraannya melenceng dari topic yang telah dibahaskan.

Dari rekapitulasi Kualifikasi Hasil Belajar PPKn Dengan Menggunakan Metode Pembelajaran Debat dapat disampaikan bahwa bila sebelumnya pada siklus I masih ada 5 orang atau $15,6 \%$ siswa yang mendapatkan nilai cukup baik pada siklus II sudah tidak ditemukan lagi siswa dengan nilai tersebut. Siswa yang mendapat nilai kategori baik 
pada siklus I mencapai 18 orang $(56,25 \%)$ pada siklus II menjadi 21 orang $(65,62 \%)$, hal ini dikarenakan siswa tersebut mengalami peningkatan prestasi belajar. sedangkan untuk kategori sangat baik juga mengalami peningkatan yaitu dimana pada siklus I berjumlah 9 orang atau 22,12\% siswa dan pada siklus II bertambah menjadi 11 orang atau $34,38 \%$ yang kategori sangat baik.

Dengan demikian temuan selama penelitian ini telah membuktikan bahwa metode pembelajaran Debat memegang peranan yang cukup besar dalam meningkatkan hasil belajar siswa. Disamping untuk nilai kognitif, penerapan model pembelajaran yang tepat juga akan mendorong siswa untuk menjadi lebih aktif dan mau terlihat secara mendalam menjadi bagian yang sesungguhnya dari proses belajar itu sendiri.

\section{PENUTUP}

\subsection{Simpulan}

Berdasarkan proses kegiatan dan hasil pembahasan penelitian, maka penulis menyimpulkan bahwa dalam proses pembelajaran, aktivitas belajar sangat ditentukan agar dapat mencapai hasil belajar siswa yang optimal. Keaktifan siswa dalam proses pembelajaran akan menyebabkan interaksi yang tinggi antara guru dengan siswa atau siswa dengan siswa lain. Hal ini akan mengakibatkan suasana kelas menjadi segar dan kondusif, dimana masing-masing siswa melibatkan kemampuannya semaksimal mungkin. Aktivitas belajar yang timbul dari siswa akan mengakibatkan terbentuknya pengetahuan dan keterampilannya yang akan mengarah pada peningkatan prestasi.

Penelitian tindakan kelas dengan penerapan metode debat pro dan kontra dalam pembelajaran PPKn telah tercapai perubahan tingkah laku siswa, baik dalam aktivitas maupun hasil belajar siswa, pada siklus I aktivitas siswa kurang baik. Hal ini terlihat dari data yang ada dengan jumlah siswa 32 orang aktivitas belajar siswa pada siklus I belum mencapai kriteria yang ditentukan dengan nilai kognitif $70 \%$ dan nilai klasikal 90\%. Tetapi prestasi pembelajaran pada siklus II tercapai $100 \%$ dan telah mencapai ketuntasan nilai yang telah ditentukan. Standar KKM yang digunakan dalam penelitian ini adalah 75 .

Berdasarkan hasil analisis data siklus I dan siklus II mengalami peningkatan presentasi kriteria ketuntasan belajar secara klasikal pada kemampuan berbicara, menyampaikan pendapat tanggapan, ideide disimpulkan bahwa "Penerapan Metode Debat Pro dan Kontra Dapat Meningkatkan Hasil Belajar PPKn Siswa Kelas VIIIB SMPN 3 Mengwi Badung.

\subsection{Saran}

Adapun saran yang dapat disampaikan penulis sebagai berikut:

Penerapan metode Debat pro dan kontra dapat dijadikan bahan acuan dalam pelaksanaan pembelajaran, selain itu guru perlu menambah wawasan tentang pembelajaran dan melatih proses serta keterampilan kepada siswa agar siswa mampu mengeksplorasikan dirinya.

Guru diharapkan untuk menciptakan suasana pembelajaran yang lebih menyenangkan agar siswa tidak bosan dengan materi yang disampaikan.

Peserta didik diharapkan lebih tekun lagi dalam belajar serta mampu melaksanakan tugas yang diberikan dikelas dengan baik dan mampuh bekerja sama dengan teman didalam proses belajar mengajar.

Siswa diharapkan agar lebih aktif mengikuti setiap kegiatan pembelajaran. Karena hal ini dapat bermanfaat bagi siswa dalam meningkatkan kemampuan. 
Bagi teman-teman sejawat yang hendak melakukan penelitian tindakan kelas yang sejenis dengan penelitian ini, hendaknya lebih mengembangkan lagi baik itu dari penggunaan metode maupun variabel yang diteliti didalamnya.

\section{DAFTAR PUSTAKA}

Ahmadi, Abu.1997. Strategi Belajar Mengajar. Pustaka Setia. Bandung.

Arikunto, Suharsimi, 2009, Dasar-dasar Evaluasi Pendidikan, Jakarta : PT. Aksara.

Depdiknas, 2006, Pendekatan dan Metode Pembelajaran PPKn SMP, Jakarta : Depdiknas.

Hamruni, 2009, Strategi dan Model Pembelajaran Aktif menyenangkan, Yogyakarta : Fakultas Tarbiyah UIN Sunan Kalijaga.

Herring, Jonathan. 2017. Cara tepat berdebat secara cerdas, meyakinkan, dan positif. Jakarta. BIP

Kaelan, 2004. Pendidikan Pancasila. Paradigma: Yogyakarta

Santika, I. G. N. (2020). Menggali dan Menemukan Roh Pancasila Secara Kontekstual. Jawa Tengah: Lakeisha.

Santika, I. G. N. (2021). Pendidikan Kewarganegaraan (Studi Komparatif Konstitusi Dengan UUD 1945). Jawa Tengah: Lakeisha.

Santika, I. G. N., Sujana, G., \& Winaya., M. A. (2019). Membangun Kesadaran Integratif Bangsa Indonesia Melalui Refleksi Perjalanan Historis Pancasila Dalam Perspektif Konflik Ideologis. Jurnal Etika Demokrasi (JED). 4 (2), 89-98. https://doi.org/10.26618/jed.v4i2.2391

Santika, I. G. N., Purnawijaya, I. P. E., \& Sujana, I. G. (2019). Membangun Kualitas Sistem Politik Demokrasi Indonesia Melalui Pemilu Dalam Perspektif Integrasi Bangsa Dengan Berorientasikan Roh Ideologi Pancasila. Seminar Nasional 1 Hukum dan Kewarganegaraan. 1 (1), 74-85
Santika, I. G. N. (2017). Kepala Sekolah Dalam Konsep Kepemimpinan Pendidikan: Suatu Kajian Teoritis. Widya Accarya. 7 (1).

Santika, I. G. N. (2020). Menelisik Akar Kegaduhan Bangsa Indonesia Pasca Disetujuinya Hasil Revisi UU KPK Dalam Perspektif Pancasila. Jurnal Ilmiah Ilmu Sosial. 6 (1), 6-36. http://dx.doi.org/10.23887/jiis.v6i1.25001

Santika, I. G. N., Rindawan, I. K., \& Sujana, I. G. (2019). Memperkuat Pancasila Melalui Pergub No. 79 Tahun 2018 Dalam Menanggulangi Pengikisan Budaya Di Era Revolusi Industri 4.0. Prosiding Seminar Nasional Inobali 2019, 79, 981-990

Santika, I. G. N. (2018). Strategi Meningkatkan Kualitas SDM Masyarakat Desa Padangsambian Kaja Melalui Pendidikan Karakter Berbasiskan Kepedulian Lingkungan Untuk Membebaskannya Dari Bencana Banjir. Widya Accarya. 9 (2).

Sardiman, A.M., 2010, Interaksi dan Motivasi Belajar Mengajar, Jakarta : Rajawali Press.

Silberman, L, Melvin. 1996. Aktive Learning. Bandung: Nusamedia.

Slameto, 2010, Belajar dan Faktor-faktor Yang Mempengaruhinya, Jakarta : Rineka Cipta.

Sugiyono, 2013, Metodologi Penelitian kuantitatif, Kualitatif Dan $R \& D$, Bandung : Alfabeta.

Sujana, Nana, 2005, Penilaian Hasil Proses Belajar, Bandung : Remaja Rosdakara.

Swarniti, N. W. (2019). The Translation Procedures of Bible Translation. RETORIKA: Jurnal Ilmu Bahasa, 5(2), 187-196. https://doi.org/10.22225/jr.5.2.1277.187-196

Tarigan, H. G. 2013. Menulis sebagai sesuatu ketrampilan berbahasa. Bandung: Angkasa 